\title{
PENGARUH RASIO KEUANGAN TERHADAP KINERJA KEUANGAN PT. FIRA FISINDO TEKNIK PALEMBANG
}

\author{
AGUS SALIM \\ Dosen Tetap Fakultas Ekonomi Universitas Palembang
}

\begin{abstract}
ABSTRAK
Penelitian ini menguji Pengaruh Pengaruh Rasio Keuangan Terhadap Kinerj Keuangan Pada PT. Fira Fisindo Teknik palemang. Tujuan dari penelitian ini adalah Untuk mengetahui perkembangan laporan keuangan PT.Fira Fisindo Teknik Palembang secara parsial dan bersamasama pada tingkat Ratio Keuangan. Dan Untuk mengetahui pengaruh ratio keuangan terhadap rasionkeuangan pada PT. Bukit Agung Sehati Palembang selama periode 2018-2020.

Tingkat rasio likuiditas pada PT.Fira Fisindo Teknik Palembang. Hal ini dikarenakan Current Ratio perusahaan yang telah mencapai $483 \%$ dan terus mengalami fluktuasi dari tahun ke tahun. Current Ratio ini mengalami fluktuasi disebabkan adanya kenaikan aktiva-aktiva lancar meskipun hutanghutang lancar juga mengalami kenaikan pada tahun 2018 tetapi diimbangi dengan meningkatnya juga aktiva-aktiva lancar yang cukup tinggi. Current Ratio yang terlalu tinggi ini dampaknya akan kurang baik .

Tingkat solvabilitas pada PT. Fira Fisindo Teknik Palembang mengalami kenaikan khususnya pada hasil perhitungan Total Assets to Debt Ratio dan pada hasil perhitungan Total Debt to Total Equity Ratio mengalami fluktuai, hal ini disebabkan karena adanya peningkatan penjualan yang pada akhirnya mempengaruhi pada laba yang diperoleh.
\end{abstract}

\section{Kata Kunci: Rasio Keuangan, Kinerja Keuangan}

\section{PENDAhuluaN}

\subsection{Latar Belakang Masalah}

Keberhasilan suatu perusahaan tidak semata-mata tergantung pada faktor diluar perusahaan yang berhubungan dengan keberhasilan perusahaan dalam persaingan merebut pasar, akan tetapi sangat dipengaruhi juga oleh faktor-faktor dari dalam perusahaan yang berkaitan dengan kemampuan manajemen perusahaan terutama dalam mengelola keuangan perusahaan. Pengelolaan uang perusahaan dapat dilihat dari laporan keuangan perusahaan yang terdiri dari laporan perhitungan rugi/laba, neraca, laporan perubahan modal dan laporan-laporan keuangan lainnya. Suatu hal yang perlu diperhatikan adalah setiap gerak pembangunan tidak akan dapat dicapai apabila tidak didukung oleh dana. Sementara dana yang diperlukan untuk membiayai pembangunan tersebut tentunya tidaklah sedikit dan dana tersebut harus dikelola dengan seefektif mungkin agar pembangunan dapat dilaksanakan dan memberikan nilai tambah yang optimal. Untuk mengambil keputusan yang rational, logis dan realistis pimpinan memerlukan informasi yang benar, lengkap dan up to date.

Laporan keuangan merupakan salah satu informasi yang diperlukan pimpinan perusahaan untuk mengambil keputusan dalam mengataasi masalah yang dihadapinya, laporan keuanagan tentunya merupakan informasi yang dapat dipercaya untuk mengetahui tentang kekayaan dan kewajiban serta perubahan-perubahan netto dari kekayaan sebagai hasil aktivitas sebuah perusahaan. Dengan mengetahui laporan keuangan periode-periode yang lalu dapat membantu memperlancar dalam hal pengambilan keputusan sehingga dapat menyusun rencana yang lebih baik pada masa yang akan datang serta memperbaiki sistem pengawasan yang ada. Disamping itu dengan adanya dana, dari mana datangnya dana tesebut dan pada sector mana dana tersebut digunakan. Untuk dapat memanfaatkan laporan keuangan, maka laporan keuangan tersebut harus dipelajari. Bagaimana cara dan usaha serta sarana untuk mengolah dana yang digunakan untuk kegiatan usahanya dalam rangka memperoleh profit yang maksimal. Demikian juga halnya analisis 
terhadap laporan rugi/laba yang mencerminkan hasil dan biaya operasi yang dicapai selama satu periode tertentu akan diperoleh gambaran atau perkembangan usaha perusahaan yang bersangkutan. Dengan menganalisa data keuangan dari tahun ke tahun yang lalu dapat diketahui kelemahan-kelemahan serta hasilhasil yang telah dianggap cukup baik, sehingga upaya peningkatan kinerja perusahaan dimasa yang akan datang dapat dilakukan dengan le bih efektif. Dalam hal ini PT.Fira Fisindo Teknik Palembang, sebagai obyek penelitian yang mana perusahaan ini adalah suatu perusahaan yang bergerak di bidang logistic dan distribusi, yaitu bergerak dibidang jasa pengiriman paket maupun dokumen. Dalam menjalankan operasinya perusahaan ini berusaha untuk memperoleh keuntungan juga untuk kelangsungan hidup perusahaan yang dapat dilihat dari laporan keuangan perusahaan.

Untuk melihat keadaan modal dan kekayaan perusahaan serta tingkat keuntungan yang diperoleh pada suatu periode tertentu, maka dapat dilihat dari laporan keuangan perusahaan. Pada umumnya laporan keuangan terdiri dari :

1. Neraca, yang menunjukkan posisi keuangan perusahaan pada suatu saat tertentu.

2. Laporan perhitungan laba-rugi, yang melaporkan tingkat keuntungan selama periode tertentu.

Berdasarkan uraian diatas penulis mencoba menyusun skripsi ini dengan judul

"FAKTOR-FAKTOR

YANG

MEMPENGARUHI RATIO LIKUIDITAS PADA LAPORAN KEUANGAN TAHUNAN PADA PT. FIRA FISINDO TEKNIK PALEMBANG “

\subsection{Perumusan Masalah}

Adapun yang menjadi permasalahan dalam penulisan ini adalah :

1.2.1 Apakah perkembangan laporan keuangan PT.Fira Fisindo Teknik Palembang secara bersama-sama mempunyai pengaruh terhadap tingkat Ratio Likuiditas?

1.2.2 Apakah perkembangan laporan keuangan PT.Fira Fisindo Teknik Palembang psecara bersama-sama mempunyai pengaruh terhadap tingkat Ratio Solvabilitas?
1.2.3 Apakah perkembangan laporan keuangan PT.Fira Fisindo Teknik Palembang secara bersama-sama mempunyai pengaruh terhadap tingkat Ratio Aktivitas?

1.2.4 Apakah perkembangan laporan keuangan PT.Fira Fisindo Teknik Palembang psecara . . bersamasama mempunyai pengaruh terhadap tingkat Ratio Profitabilitas?

\subsection{TujuanPenelitian}

1.3.1 Untuk mengetahui perkembangan laporan keuangan PT.Fira Fisindo Teknik Palembang secara bersamasama pada tingkat Ratio Likuiditas ?

1.3.2 Untuk mengetahui perkembangan laporan keuangan PT.Fira Fisindo Teknik Palembang secara bersamasama pada tingkat Ratio Solvabilitas ?

1.3.3 Untuk mengetahui perkembangan laporan keuangan PT.Fira Fisindo Teknik secara bersama-sama pada tingkat Ratio Aktivitas?

1.3.4 Untuk mengetahui perkembangan laporan keuangan PT.Fira Fisindo Teknik Palembang secara bersamasama pada tingkat Ratio Profitabilitas $?$

\subsection{Manfaat Penelitian}

Adapun manfaat dari hasil penulisan proposal ini adalah ;

\subsubsection{Bagi Perusahaan}

Manfaat penelitian bagi perusahaan adalah sebagai bahan masukan bagi perusahaan didalam mengambil suatu keputusan demi tercapainya tujuan yang diharapkan di dalam mengelola laporan keuangan pada PT.Fira Fisindo Teknik Palembang

\subsubsection{Bagi Penulis}

Melalui penelitian ini penulis diharapkan akan mendapatkan tambahan wawasan dan pengetahuan khususnya dalam bidang ilmu manajemen keuangan.

\subsubsection{Bagi Almamater}

Penelitian ini diharapkan dapat meberikan informasi serta menjadi pedoman untuk penelitian selanjutnya. 


\section{TINJAUAN PUSTAKA}

\subsection{Pengertian Laporan Keuangan}

Dalam perusahaan, laporan keuangan dimaksudkan untuk memberikan serangkaian informasi tentang keadaan keuangan serta hasil-hasil yang diperoleh perusahaan dan perkembangan perusahaan selam periode tertentu. Dengan adanya laporan keuangan pemimpin perusahaan itu dapat membuat rencana atau landasan yang kuat supaya dapat menghasilkan keputusan untuk masa yang akan datang. Serangkaian informasi yang dimaksud disusun dalam bentuk ikhtisar dalam laporan keuangan perusahaan, dalam ikatan Akuntansi Indonesia (2016:9) sebagai berikut :

"Neraca, perhitungan rugi laba, serta dapat memperjelas sifat dan perkembangan perusahaan yang dialami perusahaan dari waktu ke waktu"

Menurut Myer dalam bukunya Financial Statement Analysis, mengatakan bahwa yang dimaksud dengan laporan keuangan adalah : " Dua daftar yang disusun oleh akuntan pada akhir periode untuk suatu perusahaan. Kedua daftar ini adalah daftar neraca atau posisi keuangan dan daftar pendapatan atau daftar rugi laba. Pada saat ini sudah menjadi kebiasaan bagi perusahaan untuk menambahkan daftar ketiga yaitu daftar surplus atau daftar laba yang tidak dibagikan / laba ditahan".menurut Munawir, (2016 : 5 ). Diambil dari pengertian diatas, laporan keuangan pada umumnya terdiri dari Neraca dan Perhitungan Rugi Laba serta Perubahan Modal. Adapun pengertian dari ketiga jenis ini menurut Munawir ( $2017: 5$ ) adalah sebagai berikut :

1. Neraca adalah laporan yang sistematis tentang aktiva, hutang serta modal dari suatu perusahaan pada suatu waktu tetentu. Jadi tujuan dari neraca adalah untuk menunjukan posisi keuangan suatu perusahaan pada periode tertentu.

2. Laporan Rugi Laba adalah laporan yang sistematis tentang penghasilan, biaya, rugi laba yang diperoleholeh suatu perusahaan selam periode tertentu.

3. Perubahan Modal menunjukkan sumber dan penggunaan atau alasan yang menyebabkan perubahan modal perusahaan.

Sedangkan menurut Husnan ( 2017 :

144 ), laporan keuangan pokok terdiri dari neraca dan laporan rugi laba, dengan pengertian sebagai beriktu :

1. Neraca, menunjukkan posisi kekayaan perusahaan, kewajiban keuangan dan modal sendiri perusahaan pada waktu tertentu. Kekayaab disajikan pada sisi aktiva sedangkan kewajiban dan modal sendiri pada sisi pasiva.

Dapat terlihat pada neraca sistematisnya sebagai berikut :

\section{Kekayaan $=$ Kewajiban + Modal Sendiri}

Kebanyakan ( tetapi tidak slalu ) kekayaan perusahaan disajikan pada harga historis dan apa yang tercantum pada neraca disebut nilai buku.

2. Laporan Rugi Laba, yaitu jenis laporan yang menunjukkan laba atau rugi yang diperoleh perusahaan dalam periode waktu tertentu.

\section{Laba $($ atau rugi $)=$ Penghasilan - Biaya Total}

Dengan demikian neraca merupakan laporan yang memberikan informasi mengenai jumlah harta, hutang dan modal perusahaan pada saat tertentu. Angkaangka yang ada dalm neraca memberikan informasi yang sangat banyak mengenai keputusan yang telah diambil oleh perusahaan. Informasi tersebut dapat bersifat operasional atau strategi, baik kebijaksanaan modal kerja, investasi maupun kebijakan struktur permodalan yang telah diambil oleh perusahaan.

\subsubsection{Manfaat Laporan Keuangan}

Manfaat laporan keuangan bagi suatu perusahaan adalah untuk mengetahui sejauh mana hasil-hasil yang telah dicapai oleh perusahaan, sehingga untuk masa yang akan datang perusahaan akan lebih baik. Manfaat laporan keuangan bagi suatu perusahaan hanyalah sebagai alat penguji dari pekerja bahagian pembukuan, tapi selanjutnya laporan keuangan tidak hanya sebagai alat penguji saja tetapi juga sebagai dasar untuk menentukan atau menilai posisi keutungan perusahaan tersebut, dalam hal ini hasil analisa itu bagi pihak-pihak yang berkepentingan menghasilkan keputusan, menurut Munawir ( 2017 : 7 ). Pimpinan perusahaan dengan adanya laporan keuangan yang lalu akan dapat memberikan gambaran atau menyususn rencana yang lebih baik dimasa yang akan 
datang seperti : memperbaiki sistem pengawasannya dan menentukan keputusan yang tepat.

Disamping itu juga, menurut Munawir (2016 : 8) laporan keuangan dapat digunakan oleh manajemen untuk :

1. Mengukur tingkat biaya dari berbagai kegiatan perusahaan.

2. Untuk mengukur efisiensi tiap-tiap bagian, proses atau produksi serta untuk menentukan derajat keuntungan yang dapat dicapai oleh perusahaan yang bersangkutan.

3. Untuk menilai dan mengukur hasil kerja tiap individu yang telah diserahi wewenang dan tanggung jawab.

4. Untuk menentukan perlu tidaknya digunakan kebijaksanaan yang baru untuk mendapat hasil yang lebih baik lagi.

\subsubsection{Prosedur Analisis Laporan Keuangan}

Menururt Munawir (2016 : 34,35)

sebelum mengadakan analisis terhadap suatu laporan keuangan, penganalisa harus benar benar memahami laporan keuangan tersebut. Penganalisa harus dapat menggambarkan aktivitas-aktivitas perusahaan yang tercermin dalam laporan keuangan tersebut. Dengan kata lain bahwa agar dapat menganalisa laporan keuangan dengan hasil yang memuaskan maka perlu mengetahui latar belakang dari data keuangan tersebut. Penganalisa juga harus mempunyai kemampuan atau kebijaksanaan yang cukup dalam mengambil suatu kesimpulan,disamping harus memperhatikan dan mempertimbangkan perubahan-perubahan kondisi perusahaan juga harus mempertimbangkan perubahan tingkat harga yang terjadi. Oleh karena itu sebelum mengadakan perhitungan-perhitungan, analisis dan interprestasi, penganalisa harus mempelajari dan mereview secara menyeluruh dan kalau dianggap perlu diadakan penyusunan kembali dari data-data sesuai dengan prinsip-prinsip yang berlaku dan tujuan analisa. Maksud dari perlunya mempelajari data secara menyeluruh ini adalah untuk meyakinkan pada penganalisa bahwa laporan ini sudah cukup jelas menggambarkan semua data yang relevan dan telah diterapkan prosedur akuntansi maupun metode penilaian yang tepat.Analisis laporan keuangan sangat diperlukan oleh pihak pihak yang berkepentingan dengan perusahaan, baik dari pihak luar maupun dari pihak dalam perusahaan itu sendiri. Dalam penganalisaan menurut Bambang Riyanto ( 2018 : 329 ) pada dasarnya dapat dilakukan dengan dua macam perbandingan, yaitu :

1. Membandingkan rasio sekarang ( Present Ratio ) dengan rasio dari periode yang lalu ( Ratio Histories ) atau dengan rasio-rasio yang diperkirakan untuk waktu-waktu yang akan datang dari perusahaan yang sama.

2. Membandingkan rasio-rasio dari suatu perusahaan dengan rasio-rasio sejenis dari perusahaan lain yang sejenis pula untuk waktu yang sama.

Jadi analisis rasio keuangan merupakan kumpulan data keuangan yang dibandingkan dengan periode keperiode yang lain sehingga dapat menggambarkan situasi dan kondisi dari perusahaan. Di lain pihak, analisis rasio merupakan perbandingan laporan keuangan dari satu periode antara dua perusahaan yang sejenis.

\subsubsection{Metode dan Teknik Analisis}

Metode dan teknik analisis digunakan untuk menentukan hubungan antara pos-pos yang ada dalam laporan keuangan, sehingga dapat diketahui perubahan-perubahan dari masing-masing pos tersebut bila dibandingkan dengan laporan keuangan dari beberapa periode untuk satu perusahaan tertentu. Tujuan dari setiap metode dan tekhnik analisis adalah untuk menyederhanakan data sehingga dapat lebih dimengerti.

Pertama-tama penganalisis harus mengorganisir atau mengumpulkan data yang diperlukan untuk mengukur, kemudian menganalisis dan menginterprestasikan sehingga data tersebut lebih berarti.

Ada dua analisis yang digunakan oleh setiap penganalisis laporan keuangan ( Munawir, $2018: 36$ ), yaitu :

1. Analisis Horizontal

Yaitu analisis dengan mengadakan perbandingan laporan keuangan untuk beberapa periode atau beberapa saat, sehingga akan diketahui perkembangannya.

2. Analisis Vertikal

Yaitu analisis keuangan yang hanya meliputi satu periode atau suatu saat saja, yaitu dengan memperbandingkan 
antara pos satu dengan pos yang lainnya dalam laporan keuangan, sehingganhanya akan diketahui keadaan keuangan atau hasil operasi pada saat itu saja.

Metode dan teknik analisis data manapun yang digunakan, semuanya itu adalah merupakan permulaan dari proses analisis dan setiap metode analisis mempunyai tujuan yang sama untuk membuat data lebih dimengerti sehingga dapat digunakan sebagai dasar pengambilan keputusan bagi pihak-pihak yang membutuhkan.

\subsubsection{Analisis Rasio Keuangan}

Analisis rasio keuangan adalah alat yang paling bermanfaat untuk menentukan berbagai aktivitas usaha yang dijalankan. Pengamatan dan analisis yang memadai atas hasil analisis rasio keuangan dapat membantu manajemen untuk menemukan kelemahan dan keunggulan perusahaan ( Niki Lukuirman,2018:13).

Pada dasarnya macam atau jumlah rasio itu banyak sekali yaitu sesuai dengan kebutuhan penganalisis, namun angka-angka rasio yang ada pada dasarnya dapat digolongkan menjadi dua golongan atau kelompok (Munawir, 2017 : 68), yakni : Pertama, berdasrkan sumber data keuangan yang merupakan unsur atau elemen dari angka rasio tersebut. Kedua, berdasarkan tujuan dari penganalisa.

Apabila dilihat dari sumbernya dari mana rasio itu dibuat, maka rasio dapat digolongkan kedalam 3 golongan, yaitu :

1. Rasio-rasio neraca (Balance sheet rations ), ialah rasio-rasio yang disusun dari data yang berasal dari neraca, misalnya current ratio, acid test ratio,

current assets to total assets ratio, current liabilities to total asset ratio dan lain sebagainya.

2. Rasio-rasio laporan rugi laba (Income statement ratios ), ialah rasio-rasio yang disusun dari data yang berasal dari income statement, gross profit margin, net operating margin, operating ratio dan lain sebagainya.

3. Rasio-rasio antar laporan ( InterStatement ratios ), ialah rasio-rasio yang disusun dari data yang berasal dari neraca dan data lainnya berasal dari income statement, misalnya assets turnover, receivables turnover dan lain sebagainya.

Menurut Bambang Riyanto dalam bukunya Dasar-dasar Pembelanjaan Perusahaan ( BPFE Yogyakarta, 2017 : 331 ), pengelompokan rasio rasio yaitu sebagai berikut :

1. Rasio Likuiditas adalah rasio-rasio yang dimaksud untuk mengukur likuiditas perusahaan ( Current ratio, Acid test ratio ).

2. Rasio Leverage adalah rasio-rasio yang dimaksudkan untuk mengukur sampai berapa jauh aktiva perusahaan dibiayai dengan hutang ( Debt to total assets ratio, net worth to debt ratio dan lain sebaginya ).

3. Rasio-rasio Aktivitas, yaitu rasio-rasio yang dimaksudkan untuk mengukur sampai berapa besar efektivitas perusahaan dalam mengerjakan sumber-sumber dananya ( Inventory turnover, average collection period dan lain sebagainya ).

4. Rasio-rasio Profitabilitas, yaitu rasiorasio yang menunjukkan hasil akhir dari sejumlah kebijaksanaan dan keputusan-keputusan ( profi tmargin on Sales, Return on total assets, Return on net worth dan lain sebagainya ).

Mengingat banyaknya analisis rasio keuangan maka dalam penulisan proposal ini penulis hanya menggunakan beberapa analisis perusahaan diantaranya : Likuiditas, Solvabilitas, Aktivitas dan Profitabilitas

\section{Likuiditas}

Likuiditas adalah kemampuan suatu perusahaan memenuhi kewajiban-kewajiban keuangannya dalam jangka pendek atau yang harus segera dibayar ( J. Awat, 2018 : 385 ). Pendapat lain mengemukakan bahwa likuiditas perusahaan merupakan kemampuan perusahaan pada setiap saat untuk menyediakan alat pembayaran yang diperlukan untuk melunasi kewajiban yang jatuh tempo .Adapun kewajiban yang harus segera dibayar adalah seluruh hutang-hutang lancar yang menjadi beban bagi perusahaan dalam jangka pendek yakni waktu yang kurang dalam waktu satu tahun, dimana dalam hal ini hutang lancar dari perusahaan tersebut meliputi : hutang dagang, hutang pajak, biaya operasional, pembayaran upah buruh dan gaji 
karyawan. Tingkat kemampuan perusahaan dalam jangka pendek ini ditentukan oleh aktiva lancar, yang meliputi antara lain kas, bank, piutang dagang dan persediaan barang. Jadi kekuatan membayar hutang perusahaan adalah berupa aktiva lancar, dengan demikian maka likuiditas adalah kemampuan perusahaan dalam hal ini menyediakan alat likuid, sedemikian rupa sehingga dapat memenuhi kewajiban financialnya pada saat dilikuidasi. Apabila hutang lancar lebih besar dari harta lancar maka perusahaan berada pada sisi likuid.
Karena belum adanya standar yang resmi pada tingkat likuiditas yang harus dipertahankan oleh perusahaan, namun walaupun demikian current ratio dapat dikatakan baik apabila current ratio nya $200 \%$ atau $2: 1$, ini berarti setip Rp.1 (satu rupiah) hutang lancar dijamin oleh Rp.2 (dua rupiah ) aktiva lancar. Akan tetapi ini tidaklah mutlak hanya bersifat prinsip hati-hati, adapun ukuran yang demikian tidaklah jelek.

Cara-cara yang selalu digunakan untuk menentukan tingkat likuiditas dapat dibagi menjadi 3 macam, yaitu :

\section{a. Current Ratio}

Current Ratio yaitu perbandingan antara aktiva lancar (Current Asset) dengan hutang lancar ( Current Liabilities ). Current ratio yang memuaskan biasanya adalah kalau current assets lebih besar dari pada current liabilities. Current ratio juga menunjukkan kesanggupan perusahaan untuk membayar hutang jangka pendek.

$$
\text { Current Ratio }=\frac{\text { Aktiva Lancar }}{\text { Hutang Lancar }} \times 100 \%
$$

b. Acid test ratio ( Quick Ratio )

Quick Ratio yaitu perbandingan antara aktiva lancar tidak termasuk persediaan, karena persediaan dianggap mempunyai tingkat likuiditas rendah dengan hutang lancar.

$$
\text { Quick Ratio }=\frac{\text { Aktiva Lancar - Persediaan }}{\text { Hutang Lancar }} \times 100 \%
$$

\section{c. Cash Ratio}

Cash Ratio yaitu perbandingan jumlah kas ditambah efek-efek atau surat berharga dengan hutang jangka pendek.

$$
\text { Cash Ratio }=\frac{\text { Kas }+ \text { Bank }}{\text { Hutang Lancar }} \times 100 \%
$$

\section{Cara untuk meningkatkan likuiditas}

Untuk meningkatkan atau mempertinggi tingkat likuiditas ada beberapa cara menurut Bambang Riyanto ( $2018: 28$ ), yaitu :

a. Dengan hutang lancar tertentu berusaha memperbanyak atau menambah aktiva lancar.

b. Dengan aktiva lancar tertentu diusahakan untuk mengurangi jumlah hutang lancar.

c. Dengan mengurangi jumlah hutang lancar diiringi oleh pengurangan aktiva lancar.

d. Dengan menjual aktiva tetap yang digunakan untuk menambah aktiva lancar.

e. Dengan menambah jumlah hutang jangka panjang yang digunakan untuk menambah aktiva lancar. f. Dengan menambah setoran modal sendiri.

\section{Solvabilitas}

Solvabilitas suatu perusahaan menunjukkan kemampuan perusahaan untuk memenuhi segala kewajiban finansialnya apabila perusahaan tersebut dilikiudasi ( Bambang Riyanto, 2018 : 32 ). Dari pendapat ini sekiranya perusahaan dilikuidasi atau dibubarkan, perusahaan mampu untuk membayar atau melunasi hutang-hutangnya baik hutang jangka pendek maupun hutang jangka panjang.Kemampuan perusahaan untuk membayar hutang disebut solvabel, sedangkan ketidak mampuan perusahaan untuk membayar hutangnya disebut insovabel dengan kata lain 
perusahaan yang tidak solvabel adalah perusahaan yang total hutangnya lebih besar dibandingkan total asetnya. Jika ditinjau dari hubungan likuiditas dan solvabilitas, ada beberapa kemungkinan yang dihadapi oleh perusahaan, yaitu :

a. Perusahaan solvabel tetapi likuid. Hal ini karena perusahaan mengalami kekurangan alat-alat lancar untuk sementara, sehingga pembelianpembelian baru menjadi lebih sulit, sedangkan hutang hutang tidak dapat dibayar pada waktunya.

b. Perusahaan insovabel tetapi likuid. Keadaan ini tidak segera tampak keluar tampak keluar. Hutang-hutang yang jatuh tempo untuk jangka waktu sementara akan dilunasi secara teratur tepat pada waktunya. Keadaan ini akan membahayakan bagi para kreditur jangka panjang . Keadaan ini jika tidak segera diperbaiki, akan mengakibatkan perusahaandalam jangka panjang akan menjadi likuid.

c. Perusahaan insolvabel dan likuid. Perusahaan dihadapkan pada kesulitan yang bertumpuk-tumpuk. Pertama nilai jual harta-harta lebih kecil dari jumlah hutang-hutan. Kedua tidak tersedia cukup alat-alat lancar untuk melunasi huatang-hutang yang sudah jatuh tempo.

d. Perusahaan solvabel dan likuid. Ini adalah keadaan yang paling diinginkan setiap perusahaan. Bukan saja perusahaan memiliki nilai lebih, tetapi juga memiliki cukup alat-alat lancar untuk melunasi hutangnya yang jatuh tempo. Selain dari itu, masih ditambah dengan solvabilitas perusahaan baik, kelayakan kredit perusahaan tersebut tidak diragukan lagi.

Sebagaimana halnya likuiditas, solvabilitas juga belum ada suatu ketentuan standar yang ditetapkan, tetapi berdasarkan prinsip hati-hati, perusahaan berusaha untuk mempertahankan perusahaan dengan mengambil suatu standar yakni sebesar $100 \%$ atau $1: 1$, maksudnya setiap hutang lancar Rp.1 ( satu rupiah ) dijamin oleh harta perusahaan sebanyak Rp. 1 ( satu rupiah ). Adapun alat ukur solvabilitas yang dipakai untuk mengukur tinggi rendahnya rasio perusahaan dapat ditentukan melalui

\section{a. Total Asset to Debt Ratio}

Yakni membandingkan jumlah aktiva dengan total hutang perusahaan. Rasio ini menunjukkan pakah suatu perusahaan mampu untuk mendapatkan pinjaman baru dengan jaminan aktiva tetap.

$$
\text { Total Assets to Debt Ratio }=\frac{\text { Total Aktiva }}{\text { Total Hutang }} \quad \text { x } 100 \%
$$

\section{b. Net Worth to debt Ratio}

Yakni membandingkan jumlah modal sendiri dengan total hutang, naik itu hutang jangka pendek maupun jangka panjang. Rasio ini menunjukkan berapa besarnya modal sendiri yang ditanamkan dalam perusahaan dengan jumlah hutang yang menjadi tanggungan perusahaan.

$$
\text { Net Worth to Debt Ratio }=\quad \frac{}{\text { Total hutang }} \times 100 \%
$$

c. $\quad$ Net Worth to Fixed Assets ratio

Yaitu perbandingan antara modal sendiri dengan aktiva tetap. Rasio ini dapat mengukur kemampuan perusahaan untuk membiayai aktiva tetap dari modal sendiri. Semakin tinggi rasio berarti semakin kecil modal pinjaman yang dipergunakan untuk membiayai aktiva perusahaan.

$$
\text { Net Worth to Fixed Assets ratio }=\quad \frac{\text { Modal Sendiri }}{\text { Aktiva Tetap }} \quad \text { x } 100 \%
$$




\section{Cara untuk meningkatkan solvabilitas}

Untuk meningkatakan solvabilitas perusahaan ada beberapa cara menurut Bambang Riyanto $2018: 35$ ), yaitu :

a. Menambah aktiva tanpa menambah hutang atau menambah aktiva relatif lebih besar dari pada tambahan hutang.

b. Mengurangi hutang tanpa mengurangi aktiva atau mengurangi hutang relatif lebih besar dari pada berkurangnya aktiva.

\section{Aktivitas (Prof.Dr.Ridwan S.Sundjaya,2016)}

Ratio aktivitas adalah ratio-ratio yang digunakan untuk mengukur kecepat an beberapa perkiraan menjadi penjualan dan kas. Dalam proposal ini penulis maenggunakan 3 pendekatan, yaitu :

a. Total Assets Turn Over

Keapuan dana yang tertanam dala keseluruhan aktiva berputar dala satu periode tertentu atau keapuan modal yang diinvestasikan untuk menghasilkan peandapatan perusahaan.

\section{Total Asset turn Over $=\frac{\text { Penerimaan Penjualan }}{\text { Total Harta }}$}

b. Receivable Turn Over

Kemampuan dana yang tertanam dalam piutang beputar dala suatu periode tertentu.

$$
\text { Receivable Turn Over }=\frac{\text { Penjualan }}{\text { Piutang }}=\text { Kali }
$$

c. Working Capital Turn Over

Kemampuan modal kerja berputar dalam suatu periode tertenttu

$$
\text { Working Turn Over }=\frac{\text { Penjualan }}{\text { Aktiva }- \text { Hutang Lancar }}=\text { Kali }
$$

\section{Profitabilitas}

Merupakan hasil dari beberapa kebijakan dari keputusan yang telah diambil oleh pimpinan perusahaan.

Rasio yang digunakan pada analisa ratio profitabilitas, yaitu :

1. Gross Profit Margin

$$
=\quad \frac{\text { Lab Kotor } x}{\text { Penjualan }} 100 \%
$$

Rasio ini menunjukkan laba bersih yang dihasilkan dari setiap rupiah pendapatan.

2. Net Profit Margin

$$
=\quad \frac{\text { Lab Bersih }}{\text { Penjualan }} \times 100 \%
$$

Rasio ini menunjukkan seakin tinggi laba yangb dihasilkan dari setiap rupiah pendapatan.

3. Operating Ratio
$=$ Biaya Operasi $\times 100 \%$ Penjualan
Rasio ini enunjukkan biaya operasi per rupiah pendapatan

\subsection{Penelitian Sebelumnya}

Yuli Orniati,Universitas Gajayana

Malang (2019), "Laporan Keuangan sebagai

\section{Alat untuk Menilai Kinerja}

Keuangan"mengemukakan bahwa Hasil analisis likuiditas menunjukkan adanya peningkatan, yang membuktikan adanya peningkatan proporsi atas aktiva lancar dibandingkan dengan utang lancar yang dimiliki oleh perusahaan, sehingga beban bunga yang harus ditanggung dapat tertutupi. Kemampuan perusahaan untuk melunasi kewajiban lancarnya dengan aktiva lancar yang lebih likuid tanpa persediaan mengalami peningkatan. Keadaan tersebut dibuktikandengan adanya kenaikan prosentase pada tahun tersebut sehingga berpengaruh terhadap peningkatan kemampuan perusahaan untuk melunasi utang lancarnya. 
Tri Yanda Ramayanti (2018), “Analisis Laporan Keuangan Sebagai Salah Satu Alat Untuk Menilai Tingkat Keberhasilan Kinerja Keuangan Manajemen Pada CV. Kasur Achmad Syukri Palembang” .Berdasarkan hasil penelitian yang dilakukan, dapat disimpulkan bahwa dengan analisis laporan keuangan yang dilakukan dapat menilai tingkat keberhasilan kinerja keuangan, mengetahui kondisi dan prestasi yang telah dicapai dengan menggunakan data pokok sebagai input dalam analisis ini adalah neraca dan laporan laba rugi yang meliputi : analisis operasional, analisis manajemen sumber daya dan analisis profitabilitas. Berdasarkan analisis yang telah dilakukan hasil analisis yang diperoleh dari tahun 2018 sampai tahun 2020 dinilai sudah dapat menilai tingkat keberhasilan kinerja keuangan manajemen pada CV. Kasur Achmad Syukri.

\subsection{Kerangka Pikir}

Kerangka berpikir menggabarkan pengaruh antara variabel bebas terhadap variabel terikat yaitu pengaruh rasio likuiditas, solvabilitas, aktivitas dan profitabilitas terhadap Analisa laporan keuangan sebagai alat pengambilan keputusan pada PT.Fira Fisindo Teknik Palembang
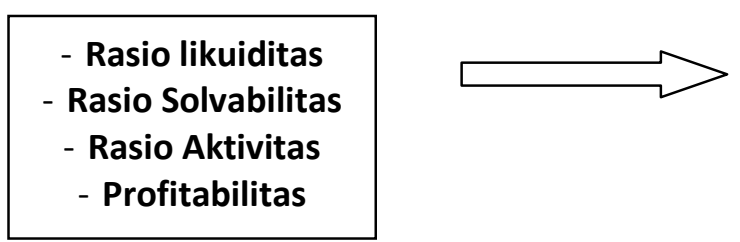

\section{Kinerja Keuangan}

\section{Gambar 1}

\section{Kerangka Pikir Hubungan antara Variabel Penelitian}

\section{METODE PENELITIAN}

\subsection{Ruang Lingkup Penelitian}

Penelitian ini dilakukan di yang berkedudukan Kelurahan Demang Lebar

Daun Jalan Mesuji Blok F-9 kecamatan Ilir Barat I kota Palembang

\subsection{Metode Pengumpulan Data}

\subsubsection{Data Primer}

Data primer adalah data yang dikumpulkan dan diperoleh secara langsung. Adapun cara yang digunakan untuk mengupulkan data primer adalah

\subsubsection{Observasi}

Yaitu cara pengumpulan data dengan melakukan pengamatan langsung terhadap kegiatan PT. Fira Fisindo Teknik Palembang .

Metode Wawancara : Metode wawancara yang digunakan oleh penulis untuk menda patkan data atau informasi yaitu melalui tehnik interview dengan pimpinan yang terkait.

3.2.1.2 Data Sekunder

Data pelengkap yang didapat dari hasil studi kepustakaan mempelajari bukubuku, mengutip teori-teori yang berhubungan dengan masalah-masalah yang dibahas.

\subsection{Teknik Analisis}

Untuk menganalisis data, penulis akan menggunakan ukuran tertentu dalam bentuk rasio keuangan, yaitu membandingkan rasio sekarang dengan rasio-rasio pada waktu yang lalu. Dan rasio yang akan digunakan adalah Rasio Likuiditas, Rasio Rentabilitas dan Rasio Aktivitas Yang terbagi lagi dalam beberapa bagian diantaranya

a. Rasio Likuiditas, yang terdiri dari :

$$
\text { Current Ratio }=\frac{\text { Aktiva Lancar }}{\text { Hutang Lancar }} \times 100 \%
$$




$$
\begin{aligned}
& \text { Quick Ratio }=\frac{\text { Aktiva Lancar - Persediaan }}{\text { Hutang Lancar }} \times 100 \% \\
& \text { Cash Ratio }=\frac{\text { Kas }+ \text { Bank }}{\text { Hutang Lancar }} \times 100 \%
\end{aligned}
$$

b. Rasio Solvabilitas, yang terdiri dari :

$$
\begin{array}{ll}
\text { Total Assets to Debt Ratio }= & \frac{\text { Total Aktiva }}{\text { Total Hutang }} \times 100 \% \\
\text { Long Term Debt to Equity }= & \frac{\text { Hutang Jangka Panjang }}{\text { Total hutang }} \times 100 \% \\
\text { Total Debt to Total Equity Ratio }= & \frac{\text { Total Hutang }}{\text { Total Modal Sendiri }} \times 100 \%
\end{array}
$$

c. Rasio Aktivitas

$$
\begin{aligned}
\text { Total Assets Turn Over } & =\frac{\text { Penerimaan Penjualan }}{\text { Total Harta }} \times 100 \% \\
\text { Receivable Turn Over } & =\frac{\text { Penjualan }}{\text { Piutang }} \times
\end{aligned}
$$$$
\text { Working Capital Turn Over }=\quad \frac{\text { Penjualan }}{\text { Aktiva }- \text { Hutang Lancar }} \times 100 \%
$$

d. Rasio Profitabilitas

$$
\begin{array}{ll}
\text { Gross Profit Margin }= & \frac{\text { Laba Kotor }}{\text { Penjualan }} \times 100 \% \\
\text { Net Profit Margin }= & \frac{\text { Laba Bersih }}{\text { Penjualan }} \times 100 \% \\
\text { Operating Ration }= & \frac{\text { Biaya Operasi } \times 100 \%}{\text { Penjualan }}
\end{array}
$$

\section{HASIL PENELITIAN DAN PEMBAHASAN}

\subsection{Ratio Likuiditas}

Rasio Likuiditas, yang terdiri dari :

$$
\begin{aligned}
& \text { Current Ratio }=\quad \frac{\text { Aktiva Lancar }}{\text { Hutang Lancar }} \times 100 \% \\
& \text { Quick Ratio }=\frac{\text { Aktiva Lancar - Persediaan }}{\text { Hutang Lancar }} \times 100 \%
\end{aligned}
$$




$$
\text { Cash Ratio }=\frac{\text { Kas }+ \text { Bank }}{\text { Hutang Lancar }} \times 100 \%
$$

\subsubsection{Rasio Solvabilitas, yang terdiri dari :}

\begin{tabular}{ll} 
Total Assets to Debt Ratio $=$ & Total Aktiva \\
\cline { 2 - 2 } Long Term Debt to Equity $=$ & $\frac{\text { Total Hutang }}{\text { Hutang Jangka Panjang }}$ \\
Total Debt to Total Equity Ratio $=$ & $\begin{array}{l}\text { Total hutang } \\
\text { Total Hutang } \times 100 \%\end{array}$ \\
Total Modal Sendiri
\end{tabular}

\subsubsection{Rasio Aktivitas}

$$
\begin{aligned}
\text { Total Assets Turn Over } & =\frac{\text { Penerimaan Penjualan } \mathrm{x}}{\text { Total Harta }} \\
\text { Receivable Turn Over } & =\frac{\text { Penjualan }}{\text { Piutang }}
\end{aligned}
$$$$
\text { Working Capital Turn Over }=\frac{\text { Penjualan }}{\text { Aktiva }- \text { Hutang Lancar }}
$$

\subsubsection{Rasio Profitabilitas}

$$
\begin{array}{ll}
\text { Gross Profit Margin }= & \frac{\text { Laba Kotor } \times 100 \%}{\text { Penjualan }} \\
\text { Net Profit Margin }= & \frac{\text { Laba Bersih } \quad \text { Penjualan }}{\text { Biaya Operasi } \times 100 \%} \\
\text { Operating Ration }= & 100 \%
\end{array}
$$

\subsection{Hasil Penelitian}

\subsubsection{Analisa Ratio Likuiditas}

Likuiditas adalah kemampuan perusahaan dalam menganalisa posisi keuangan jangka pendek yaitu untuk mengetahui kemampuan perusahaan dalam menyediakan alat-alat yang likuid, guna menjamin pengembalian hutang-hutang jangka pendek tepat pada waktunya. Dalam ratio Likuiditas peralatan yang penulis gunakan :

\section{a. Current Ratio}

$$
\begin{aligned}
& \text { Aktiva Lancar } \\
& \text { Current Ratio }=\quad \begin{array}{c}
\text { - } \\
\text { Hutang Lancar }
\end{array}
\end{aligned}
$$

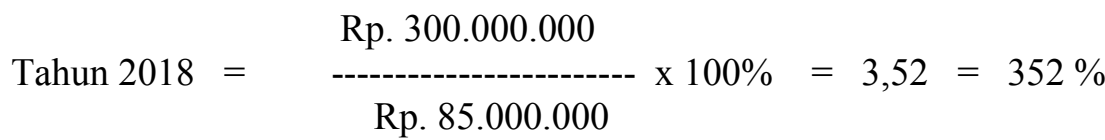




$$
\begin{aligned}
& \text { Tahun } 2019=\frac{\text { Rp. } 326.500 .000}{- \text { Rp. } 67.500 .000} \times 100 \%=4,83=483 \% \\
& \text { Rahun } 2020=\quad \begin{array}{l}
\text { Rp. } 342.000 .000 \\
- \text { Rp. } 78.500 .000
\end{array}
\end{aligned}
$$

Current Ratio pada tahun 2018 adalah berjumlah 352\% yang berarti kemampuan perusahaan untuk membayar Rp. 1 hutang lancar dijamin oleh 3,52 aktiva lancar, sementara untuk tahun 2019 setiap Rp. 1 hutang lancar dijamin oleh 4,83\% aktiva lancar dan untuk tahun 2020 setiap Rp. 1 hutang lancar dijamin 4,35 aktiva lancar. Dari keadaan tersebut menunjukan bahwa tingginya tingkat Current Ratio yang disebabkan besarnya dana pada uang kas, sehingga dampaknya kurang baik .

\section{b. Cash Ratio}

$$
\begin{aligned}
\text { Cash Ratio }= & \frac{\text { Kas }}{\text { Hutang Lancar }} \times 100 \% \\
\text { Tahun } 2018= & \frac{\text { Rp. } 100.000 .000}{\text { Rp. } 85.000 .000} \times 100 \% \\
= & 1,17 \text { atau } 117 \\
\text { Tahun } 2019 & =\frac{\text { Rp. } 111.500 .000,-}{\text { Rp. } 67.500 .00} \times 100 \% \\
\text { Tahun } 2020 & =\frac{1,65 \text { atau } 165 \%}{\text { Rp. } 117.000 .000} \times 100 \% \\
& =2,41 \text { atau } 241 \%
\end{aligned}
$$

Cash Ratio dari perhitungan diatas terlihat setiap tahunnya ada peningkatan. Hal ini disebabkan oleh adanya kas perusahaan yang dibanding dengan hutang lancar, Cash Ratio yang tinggi akan mengurangi potensi untuk mempertinggi Rate Of Return.

\section{c. Quich Ratio}

$$
\text { Quich Ratio }=\frac{\text { Aktiva Lancar }- \text { Persediaan } \quad \text { x100 }}{\text { Hutang Lancar }}
$$

Tahun $2018=\frac{\text { Rp. } 300 \cdot 000}{\text { Rp. } 85 \cdot 000 \cdot 000} \times 100 \%$

$$
=\quad 0,35 \%
$$

$$
\text { Rp. 326.500.000,- } \quad \text { x 100\% }
$$

$$
\begin{aligned}
\text { Tahun } 2019 & = & \text { Rp. } 67.500 .000 \\
& = & 4,83 \%
\end{aligned}
$$




$$
\begin{aligned}
\text { Tahun } 2020= & \frac{\text { Rp. } 342 \cdot 000 \cdot 000,-}{\text { Rp. } 48 \cdot 500 \cdot 000} \times 100 \% \\
= & 7,05 \%
\end{aligned}
$$

Quich Ratio mengalami peningkatan dari tahun ketahun, dimana pada tahun 2018 Quich rationya 0,35\%, tahun 2019 4,83\% dan tahun 2020 mengalami kenaikan sebesar 7,05\%.

\subsubsection{Analisa Ratio Solvabilitas}

Rasio Solvabilitas, yang terdiri dari :

a. Total Assets to Debt Ratio

$$
\begin{aligned}
& \text { Total Aktiva } \\
& \text { Tahun } 2018=\frac{1.096 .000 .000}{85.000 .000} \times 100 \% \\
& =12,8 \% \\
& \text { Tahun } 2019=\frac{1.096 .758 .333}{67.500 .000} \times 100 \% \\
& =16 \text {, } \\
& \text { Tahun } 2020=\frac{1.121 .950 .000}{48.500 .000,-} \times 100 \% \\
& =23,13 \%
\end{aligned}
$$$$
\text { Total Assets to Debt Ratio }=\quad \text { Total Hutang } \quad \text { x } 100 \%
$$

Total Assets to Debt Ratio mengalami nkenaikan tiap tahunnya pada tahun 2018 adalah berjumlah 12,8\% dan mengalami peningkatan sebesar 16,2\% pada tahun 2019 dan pada tahun 2020 mengalami peningkatan kembali sebesar 23,13\%.

b. Total Debt to Total Equity Ratio =

\section{Total Hutang $\quad x 100 \%$ Total Modal Sendiri}

$$
\begin{aligned}
\text { Tahun } 2018 & =\frac{85.000 .000}{1.011 .000 .000,-} \times 100 \% \\
& =8,4 \% \\
\text { Tahun } 2019 & =\frac{67.500 .000}{1.029 .258 .333} \times 100 \% \\
& =6,5 \% \\
\text { Tahun } 2020 & =\frac{48.500 .000,}{} \times 100 \% \\
& =4,5 \%
\end{aligned}
$$

Total Debt to Total Equity Ratio mengalami penurunan tiap tahunnya dimana pada tahun 2018 Total Debt to Total Equity Ratio sebesar 8,4\%, tahun 2019 sebesar 6,5\% dan mengalami penurunan kembali pada tahun 2020 sebesar $4,5 \%$ 


\subsubsection{Rasio Aktivitas}

a. Total Assets Turn Over

\section{$=\underset{\text { Potal Harta }}{\text { Penerimaan }}$}

$$
\begin{array}{ll}
\text { Tahun } 2011= & \frac{800.000 .000}{660.586 .500} \mathrm{X} \\
& =1,21 \mathrm{X} \\
& =\frac{850.000 .000,-}{710.106 .750,-} \\
\text { Tahun } 2012 & \times 100 \% \\
& =\frac{1,19 \mathrm{X}}{758.986 .470} \mathrm{X} \\
\text { Tahun } 2013= & 1,18 \mathrm{X}
\end{array}
$$

Total Assets Turn Over mengalami penurunan tiap tahunnya dimana pada tahun 2011 Total Assets Turn Over sebesar 1,21 X, tahun 2012 sebesar 1,19 X dan mengalami penurunan kembali pada tahun 2013 sebesar 1,18 X.

b. Working Capital Turn Over $=$

\section{$\frac{\text { Pendapatan }}{\text { Aktiva - Hutang Lancar }}$}

Tahun 2018

$$
\begin{aligned}
& =\frac{800.000 .000}{1.096 .000 .000-85.000 .000} \mathrm{X} \\
& =\quad \frac{800.000 .000}{1.011 .000 .000} \mathrm{X} \\
& =\quad 0,79 \mathrm{X}
\end{aligned}
$$

Tahun 2019

$$
\begin{aligned}
& =\quad \frac{850.000 .000}{1.029 .258 .333-67.500 .000,-} \mathrm{X} \\
& =\quad \frac{850.000 .000 \times 100 \%}{961.758 .333} \\
& =\quad 0,88 \mathrm{X}
\end{aligned}
$$

Tahun 2020

$$
\begin{aligned}
& =\frac{900.000 .000}{1.073 .450 .000-48.500 .000} \mathrm{X} \\
& =\quad \frac{900.000 .000}{1.024 .950 .000} \mathrm{X} \\
&
\end{aligned}
$$

Working Capital Turn Over mengalami fluktuasi tiap tahunnya dimana pada tahun 2018 Working Capital Turn Over sebesar 0,79 X, tahun 2019 sebesar 0,88 X dan mengalami penurunan kembali pada tahun 2020 sebesar $0,87 \mathrm{X}$.

\subsubsection{Rasio Profitabilitas}
a. Gross Profit Margin = Laba Kotor $\quad x \mathbf{1 0 0 \%}$ 


$$
\begin{aligned}
\text { Tahun } 2018 & =\frac{757.860 .000, \times 100 \%}{800.000 .000} \\
& =94,7 \% \\
\text { Tahun } 2019 & =\frac{812.932 .500}{850.000 .000} \times 100 \% \\
& =\frac{95,6 \%}{867.818 .300} \times 100 \% \\
\text { Tahun } 2020 & \\
& =103 \%
\end{aligned}
$$

Gross Profit Margin mengalami kenaikan tiap tahunnya dimana pada tahun 2018 Gross Profit Margin sebesar 94,7\%, tahun 2019 sebesar 95,6\% dan mengalami kenaikan kembali pada tahun 2020 sebesar $103 \%$.

$$
\begin{aligned}
& \text { b. Net Profit Margin = } \\
& \underline{\text { Laba Bersih }} \times 100 \% \\
& \begin{aligned}
& \text { Tahun } 2018 \quad=\quad 660.586 .500 \times 100 \% \\
& 800.000 .000 \\
& 82,5 \%
\end{aligned} \\
& \text { Tahun } 2019=\frac{710.106 .750}{850.000 .000} \times 100 \% \\
& =\quad 83,5 \% \\
& \text { Tahun } 2020=\frac{758.986 .470}{867.818 .300} \times 100 \% \\
& =\quad 87,4 \%
\end{aligned}
$$

Net Profit Margin mengalami kenaikan tiap tahunnya dimana pada tahun 2010 Net Profit Margin sebesar 82,5\%, tahun 2011 sebesar 83,5\% dan mengalami kenaikan kembali pada tahun 2012 sebesar $87,4 \%$.

$$
\begin{aligned}
& \text { Operating Ration = } \\
& \text { Pendapatan } \\
& \text { Tahun } 2018=\frac{42.140 .000 \times 100 \%}{800.000 .000} \\
& =\quad 5,2 \% \\
& \text { Tahun } 2019=\frac{37.067 .500}{850.000 .000} \times 100 \% \\
& =\quad 4,3 \% \\
& \text { Tahun } 2020=\frac{32.181 .700 \times 100 \%}{867.818 .300} \\
& =\quad 3,7 \%
\end{aligned}
$$$$
\text { Biaya Operasi } \times 100 \%
$$ 
Operating Ration mengalami penurunan tiap tahunnya dimana pada tahun 2018 Operating Ration sebesar 5,2\%, tahun 2019 sebesar 4,3\% dan mengalami penurunan kembali pada tahun 2020 sebesar $3,7 \%$.

\section{KESIMPULAN DAN SARAN}

Berdasarkan data laporan keuangan dari PT.Fira Fisindo Teknik Palembang dan analisa yang telah penulis lakukan dalam bab empat, maka berikut ini sebagai bagian akhir dari penulisan skripsi ini penulis mengambil suatu kesimpulan sesuai dengan pokok permasalahan yang ada dan penulis mencoba memberikan saran-saran yang kiranya dapat membantu memberikan jalan keluar dari masalah tersebut.

\subsection{Kesimpulan}

1. Tingkat rasio likuiditas pada PT.Fira Fisindo Teknik Palembang .Hal ini dikarenakan Current Ratio perusahaan yang telah mencapai $483 \%$ dan terus mengalami fluktuasi dari tahun ke tahun. Current Ratio ini mengalami fluktuasi disebabkan adanya kenaikan aktivaaktiva lancar meskipun hutang-hutang lancar juga mengalami kenaikan pada tahun 2018 tetapi diimbangi dengan meningkatnya juga aktiva-aktiva lancar yang cukup tinggi. Current Ratio yang terlalu tinggi ini dampaknya akan kurang baik .

2. Tingkat solvabilitas pada PT.Fira Fisindo Teknik Palembang mengalami kenaikan khususnya pada hasil perhitungan Total Assets to Debt Ratio dan pada hasil perhitungan Total Debt to Total Equity Ratio mengalami fluktuai, hal ini disebabkan karena adanya peningkatan penjualan yang pada akhirnya mempengaruhi pada laba yang diperoleh.

3. Tingkat Aktivitas, pada hasil perhitungan Total Assets Turn Over mengalami penurunan sebesar $9 \%$ dan Working Capital Turn Over mengalami fluktuasi.

4. Tingkat profitabilitas mengalami kenaikan tiap tahunnya. Hasil perhitungan profitabilitas Gross Profit Margin naik sebesar 9\%, sedangkan Net Profit Margin mengalami kenaikann juga sebesar $1 \%$ dan hasil perhitungan Operating Ration mengalami penurunan.

\subsection{Saran - Saran}

1. Current Ratio dan Acid Test Ratio berhubungan dengan likuiditas perusahaan jangka pendek. Hal ini berpengaruh terhadap pertimbangan pemberian kredit oleh kreditur, serta kepercayaan terhadap perusahaan karena agar Current Ratio dan Acid Test Ratio menurunkan rasio likuiditas mencapai $200 \%$. Untuk mencapai Current Ratio yang dikehendaki yaitu dengan mengatur aktiva lancar perusahaan jangan sampai terlalu besar sehingga kecenderungan mengendap sehingga sangat berpengaruh terhadap rentabilitas perusahaan

2. Pimpinan perusahaan sebaiknya menetapkan tingkat Profit Margin dan Earning Power yang harus dicapai. Hal ini berguna untuk dapat membuat perencanaan biaya sehingga menjadi seefisien mungkin. Dengan adanya perencanaan biaya, maka apa yang harus dikeluarkan menjadi biaya sudah direncanakan secara matang agar apa yang seharusnya dikeluarkan dapat bermanfaat secara efisien dan seefektif mungkin.

3. Pimpinan perusahaan sebaiknya mempertimbangkan kembali Aktiva Tetap Gedung yang penggunaannya diperuntukan sebagai kantor perusahaan, karena biaya sewa kantor masih dimungkinkan akan lebih murah dibanding biaya penyusutan gedung itu sendiri sehingga efisiensi dari biaya operasi ini diharapkan akan meningkatkan tingkat laba yang diperoleh perusahaan.

\section{DAFTAR PUSTAKA}

Ati Susanti, dengan judul "Pengaruh Perputaran Modal Kerja Terhadap Profitabilitas" Cetakan Kesembilan, Penerbit Cipta,Jakarta,2016

Ariyanto, Dasar-Dasar Modal Kerja, Cetakan Kesembilan, Penerbit 
Alwi, Syafarudin, Alat-alat Analisis dalam pembelanjaan, Yogyakarta, Andi offset, 2018

Bhaduri, Analisis Laporan Keuangan, Yogyakarta, Liberty, 2016

Djahidin, Peneltian tentang status obyek penelitian, 2017

Fahmi, Irham. 2018. Analisis Kinerja Keuangan. cet 3. Bandung : Alfabeta

Gitman. 2018 Analisis Multiva riate Lanjutan dengan Program SPSS. Badan Penerbit Universitas Diponegoro. Semarang.

Jumingan, 2017, Dasar-Dasar Modal Kerja, Cetakan Kesembilan, Penerbit Cipta,Jakarta

Kasmir. 2018. Analisis Faktor-Faktor Yang Mem pengaruhi Ketepatan Waktu Penyam paian Laporan Keuangan. Simpo sium Nasional Akuntansi XI Ikatan Indonesia. H.1-22.

Munawir. Dasar-Dasar Modal Kerja, Jakarta,2018

Riyanto, Bambang, Dasar-dasar Pembelanjaan Perusahaan, Edisi ketujuh, Penerbit BPFE, Yogyakarta, 2018

Rizal Rizaludin , "Pengaruh Modal Kerja Terhadap Sisa Hasil Usaha",2019 